\title{
ANALISIS STABILITAS TIMBUNAN (MAINDAM) BERDASARKAN DATA INSTRUMEN GEOTEKNIK PADA BENDUNGAN SINDANG HEULA SERANG BANTEN
}

\author{
Nanang Sutisna1, M. Ichwanul Yusup², dan Euis Amilia ${ }^{3}$ \\ ${ }^{1,2}$ Program Studi Teknik Sipil, Universitas Banten Jaya, Jl. Raya Ciwaru II No.73 Kota Serang, \\ Banten \\ Email: nanangsutisna45@yahoo.com \\ Email: ichwanulyusup@yahoo.com \\ Email: euisamilia@yahoo.com
}

\begin{abstract}
ABSTRAK
Kerusakan atau runtuhnya suatu bendungan dapat terjadi karena beberapa hal, diantaranya adalah melimpasnya air diatas mercu bendungan (overtopping), longsornya lereng bendungan (sliding), terbawanya butiran tanah dari tubuh bendungan (internal erosion atau "piping") dan lain sebagainya. Berdasarkan hasil survey lapangan di Bendungan.Sindang Heula ada beberapa titik di atas bangunan inti (maindam) yang mengalami penurunan struktur, untuk mengetahui pengaruh penurunan struktur tersebut maka dilakukan pengambilan data ukur inclinometer dan piezometer guna mengetahui permasalah yang mengakibatkan penurunan kontruksi / struktur tersebut. Menurut statistik dan penelitian para ahli, menyatakan bahwa lebih kurang 85\% kerusakan bendungan adalah disebabkan oleh pengaruh hidraulik dan rembesan air, yang biasanya sulit dihitung secara teliti, hal ini berarti bahwa desain suatu bendungan tidak semuanya dapat dihitung secara teoritis Setelah melakukan penelitian dan studi lapangan di bendungan sindang heula ada beberapa titik mengalami penurunan pada bagian atas timbunan inti (maindam), Metode perhitungan ini digunakan oleh Soil Instruments Vibrating Wire Penebang (model RO-1-VW-1 atau 2 dan dengan nomor seri mulai VL atau TVL) prosesor internal, untuk menghitung dan menampilkan langsung dilayar LCD penebang, unit berbasis 'teknik' yang diperlukanUntuk mengetahui penyebab penurunan tersebut dilakukan lah pengambilan data alat ukur instrument geoteknik. Terjadinya penurunan struktur atas Bendungan Sindang Heula bukan di sebabkan karrna adanya rembesan atau pun gaya yang bekerja pada tubuh bendungan, hal ini diketahui setelah melalui tahapan observasi di lapangan dengan cara perhitungan hasil data ukur alat inclinometer, piezometer, sencon dan CBR. pergerakan tersebut bukan di sebabkan karna adanya kerusakan pada bendungan melainkan ketika masa kontruksi kurangnya pengawasan.
\end{abstract}

Kata Kunci: Bendungan Sindang Heula, inclinometer dan piezometer, Instrumen Geoteknik.

\section{PENDAHULUAN}

Semakin berkembangnya ilmu pengetahuan dan teknologi telah mendapatkan teknologi pendukung pemantauan terhadap gaya geser tanah dan tekanan air pori pada bendungan, adanya gaya geser terhadap tanah urugan dan tekanan air pori melaui rongga-rongga kecil yang terdapat di tanah urugan pada tubuh bendungan akan dapat di deteksi dengan peralatan seperti inclinometer dan piezometer yang sudah di pasang pada titik yang sudah di tentukan. Penerapan teknologi inclinometer dan piezometer ini di pakai sebagai alat pendukung pemantauan pergerakan tanah urugan dan tekanan air pori terhadap bendungan.

Kerusakan atau runtuhnya suatu bendungan dapat terjadi karena beberapa hal, diantaranya adalah melimpasnya air diatas mercu bendungan (overtopping), longsornya lereng bendungan (sliding), 
terbawanya butiran tanah dari tubuh bendungan (internal erosion atau "piping") dan lain sebagainya. Berdasarkan hasil survey lapangan di Bendungan Sindang Heula ada beberapa titik di atas bangunan inti (maindam) yang mengalami penurunan struktur, untuk mengetahui pengaruh penurunan struktur tersebut maka dilakukan pengambilan data ukur inclinometer dan piezometer guna mengetahui permasalah yang mengakibatkan penurunan kontruksi / struktur tersebut. Menurut statistik dan penelitian para ahli, menyatakan bahwa lebih kurang $85 \%$ kerusakan bendungan adalah disebabkan oleh pengaruh hidraulik dan rembesan air, yang biasanya sulit dihitung secara teliti, hal ini berarti bahwa desain suatu bendungan tidak semuanya dapat dihitung secara teoritis.

Instrument Geoteknik bendungan adalah segala jenis peralatan yang dipasang pada tubuh maupun pondasi bendungan guna memantau kinerja atau perilaku bendungan, baik selamasa konstruksi maupun pada tahap operasinya. Dengan demikian diharapkan bahwa segala bentuk peyimpangan dan perubahan yang terjadi dapat diketahui lebih awal, sehingga tindakan terhadap hal-hal yang tidak diinginkan dapat dilakukan sedini mungkin dan menjaga/menjamin keamanannya. Lebih dari itu, secara umum maksud pemasangan instrumentasi bendungan menurut sumber Kementrian Pekerjaan Umum dan Rumah Rakyat (PUPR). diantaranya adalah sebagai berikut :

1. Selain sebagai alat pemantau, pemasangan instrumentasi bendungan sekaligus untuk memperoleh rekaman data sebagai bahan kajian, apakah desain bendungan betul-betul sudah memadai dan cocok atau sesuai kondisi Iapangan yang ada.

2. Membantu dalam mencegah efek negatif yang mungkin timbul sebagai akibat ketidak sempurnaan desain yang disebabkan oleh faktor-faktor yang belum diketahui sebelumnya.

3. Bersama-sama dengan hasil uji kendali mutu di lapangan, data pembacaan instrumen bisa digunakan sebagai alat bantu dalam rangka mengevaluasi hasil penerapan suatu metode terapan maupun modifikasi teknologi untuk keperluan pengembangan di bidang desain bendungan yang akan datang.

Untuk mendiagnosa dalam menentukan seluk-beluk dan penyebab terjadinya kegagalan atau kerusakan bendungan

Inclinometer merupakan alat kontruksi yang memiliki fungsi untuk penganalisaan pada kemiringan dan timbunan yang terjadi pada tanah. Misalnya pada tanah yang berpotensi besar terjadinya longsor atau pada tanah yang terletak pada dinding trowongan, bendung, bendungan, lereng dan lainnya.

Untuk mengukur/memantau gerak-gerak mendatar (Lateral) sering kali terjadi pada batuan pondasi, tubuh bendungan ataupun pada bukit tumpuan. Juga gerak-gerak vertikal atau amblesan yang diakibatkan oleh proses konsolidasi. Karena mempunyai 2 (dua) fungsi ganda sekaligus, pengoperasian dan perawatannya membutuhkan opetator yang betul-betu terlatih baik serta berpengalaman sehingga mengetahui ada tidaknya penyimpangan dan anomalianomali yang terjadi. Peralatan inklinometer terdiri atas serangkaian pipa-pipa selongsong (casing) dari alumimium (panjang 1,5-3 m) yang bagian dalamnya mempunya 2 (dua) pasang alur yang posisinya saling tegak lurus danberfungsi sebagai pegangan roda dari alat ukur atau probe (servo accelerometer) yang sering disebut Inklinometer Probe. Berdasarkan instalasi dan kepentingannya, terdapat 2 (dua) jenis inclinometer:

1. Instalasi Normal yang dipasang pada lokasi-lokasi yang mudah dijangkau atau dicapai oleh Operator. Disamping relatif lebih murah, pengukuran bisa dilakukan terhadap casing joint di sepanjang lubang (casing).

2. Posisi Tetap (Fixed Position) yang biasa dipasang pada lokasi-Iokasi tidak mungkin dijangkau, misalnya pada lereng hulu bendungan di bawah kofam waduk. Peralatan dan instalasinya relatif lebih mahal karena selain pembacaannya menggunakan sistem jarak jauh (remote) juga diperlukan peralatan sensor khusus. Oleh karena itu, pada umumnya hanya untuk memantau tempat-tempat atau kedaLaman tertentu saja yang dianggap rawan.

Penelitian ini dilakukan pada tanggal 15 Maret 2020 di Bendungan Sindang Heula yang secara administratif berada di Sungai Cibanten, Dusun Serut, Desa Sindangheula, Kecamatan Pabuaran Kabupaten Serang Provinsi Banten.Koordinat Bendungan : Letak Bendungan pada Koordinat $106^{\circ}$ 5'BT s.d $106^{\circ} 10^{\prime}$ BT. $06^{\circ} 5^{\prime}$ LS s/d. 06 $15^{\prime}$ LS. Luas : Luas DAS Sindang Heula (G) adalah 74,46 Km. 


\section{METODE PENELITIAN}

Pengambilan dan pengolahan data yang dipakai dalam studi kali ini menggunakan metode gabungan studi pustaka dan studi lapangan. Yang diharapkan dapat memperoleh hasil dan data secara optimal guna mendukung penelitian dan pemahaman secara langsung.

\section{PEMBAHASAN}

Data ukur alat inclinometer diambil dengan rentan waktu 5 hari, 1 kali pengambilan dalam 1 minggu untuk setiap bacaan minus (-) menandakan adanya pergerakan dalam tubuh bendungan kearah hulu dan sebaliknya bila hasil tidak ada tanda minus berarti adanya pergerakan kearah hilir bendungan.

Pengertian :

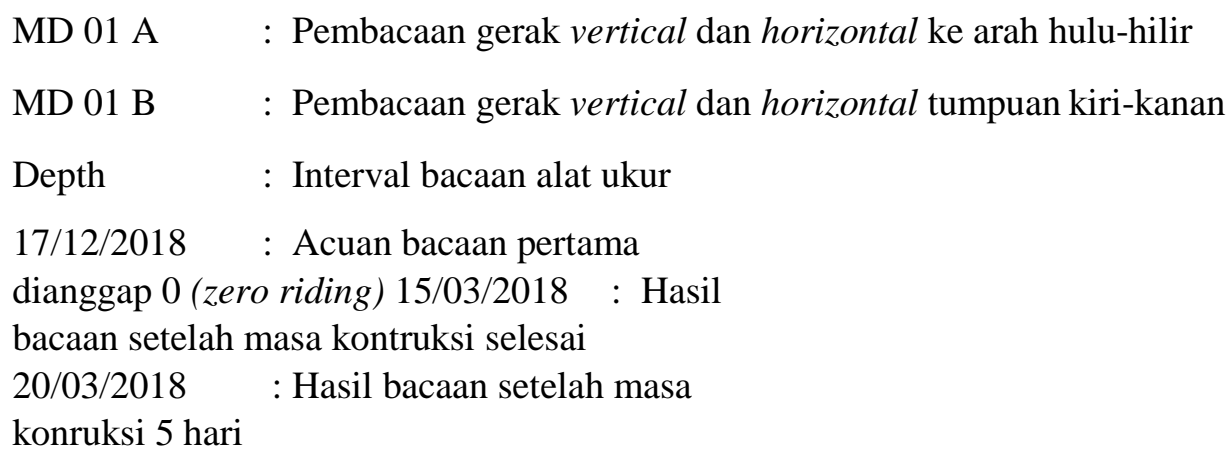

Tabel 1. Hasil Pengukuran Pergerakan Vertical A-A

Depth in Meters: Profile_Change: Profile Change in $\mathbf{~ m m}$

\begin{tabular}{cccccc}
\hline & Depth & $\begin{array}{c}17 / 12 / 20 \\
18\end{array}$ & $15 / 03 / 2020$ & $\begin{array}{c}20 / 03 / 20 \\
20\end{array}$ & $\begin{array}{c}25 / 03 / 20 \\
20\end{array}$ \\
\hline 1 & 0.50 & 0.00 & 335.17 & 336.34 & 336.42 \\
2 & 1.00 & 0.00 & 307.65 & 308.81 & 308.88 \\
3 & 1.50 & 0.00 & 283.04 & 284.21 & 284.26 \\
4 & 2.00 & 0.00 & 260.84 & 262.01 & 262.05 \\
5 & 2.50 & 0.00 & 242.61 & 243.76 & 243.81 \\
6 & 3.00 & 0.00 & 227.79 & 228.92 & 228.97 \\
7 & 3.50 & 0.00 & 214.76 & 215.90 & 215.96 \\
8 & 4.00 & 0.00 & 201.42 & 202.55 & 202.64 \\
9 & 4.50 & 0.00 & 189.42 & 190.56 & 190.63 \\
10 & 5.00 & 0.00 & 180.28 & 181.42 & 181.53 \\
\hline
\end{tabular}

Dari tabel 1.diatas didapatkan dengan kedalaman 5.00 hasil Pengukuran Pergerakan Vertical A-A didapatkan niai sebesar 181,53. Hal ini disebabkan bahwa semakin besar kedalamannya maka perubahan profil semakin kecil. 
Tabel 2. Hasil Pengukuran Pergerakan Vertical A-A

Depth in Meters: Profile_Change: Profile Change in $\mathbf{~ m m}$

\begin{tabular}{cccccc}
\hline No & Depth & $\begin{array}{c}17 / 12 / 2 \\
018\end{array}$ & $15 / 03 / 2020$ & $20 / 03 / 2020$ & $\begin{array}{c}25 / 03 / 2 \\
020\end{array}$ \\
\hline 1 & 0.50 & 0.00 & -48.98 & -48.99 & -50.34 \\
2 & 1.00 & 0.00 & -45.70 & -45.72 & -47.06 \\
3 & 1.50 & 0.00 & -43.11 & -43.15 & -44.46 \\
4 & 2.00 & 0.00 & -42.35 & -42.40 & -43.69 \\
5 & 2.50 & 0.00 & -42.66 & -42.73 & -44.00 \\
6 & 3.00 & 0.00 & -43.64 & -43.70 & -44.97 \\
7 & 3.50 & 0.00 & -45.11 & -45.17 & -46.41 \\
8 & 4.00 & 0.00 & -46.95 & -47.02 & -48.25 \\
9 & 4.50 & 0.00 & -48.29 & -48.39 & -49.64 \\
10 & 5.00 & 0.00 & -48.40 & -41.85 & -49.71 \\
\hline
\end{tabular}

Dari tabel 2. Diatas didapatkan hasil dengan kedalaman 5.00 didapatkan nilai sebesar -49.71 . Hasil Pengukuran Vertikal A.A didapatkan hasil $-49.71 \mathrm{~mm}$
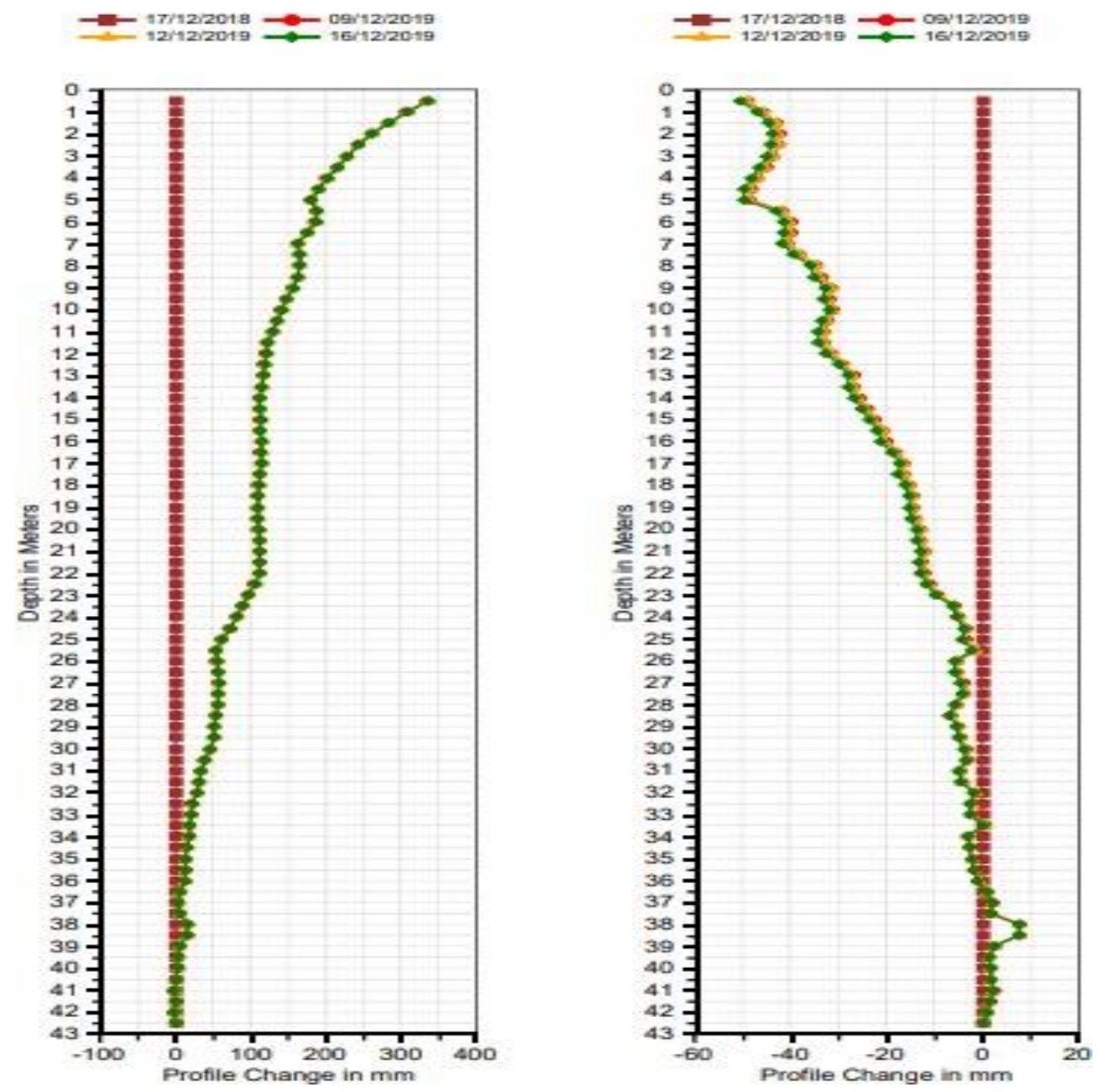

Grafik 1. Profile Change in $\mathrm{mm}$ 


\section{Keterangan :}

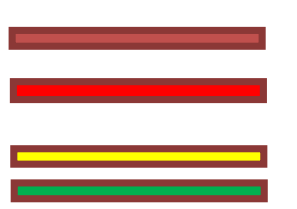

$$
\begin{aligned}
& =\text { Pembacaan yang di jadikan zero riding hasil dari kalibrasi } \\
& =\text { Pembacaan alat ukur selama masa kontruksi }(09 / 12 / 2019) \\
& =\text { Pembcaan alat ukur setelah } 3 \text { Hari selesai masa kontruksi }(12 / 12 / 2019) \\
& =\text { Pembacaan alat ukur dengan interval } 1 \text { minggu }(16 / 12 / 2019)
\end{aligned}
$$

Pada pemeriksaan kestabilan serta pengawasan konstruksi pekerjaan tanah, diperlukan data perubahan tekanan air pori pada tempat tertentu sebelum kita bisa menganalisis prinsip-prinsip tekanan effektif. Prinsip dasar bekerjanya piezometer adalah bahwa suatu elemen yang porus dari pisometer dimasukkan ke dalam tanah, sehingga air tanah dapat masuk kedalamnya dan terkumpul di dalam unit elemen. Pengukuran permukaan air atau tekanan air di dalam alat pisometer dapat dapat digunakan untuk enghitung besarnya tekanan air pori.

Berdasarkan prinsip kerjanya, terdapat 2 macam pisometer, yaitu sistem terbuka dan sistem tertutup. Jenis alat ukur tekanan air pori dan air tanah sistem terbuka, diantaranya adalah :

1. Pisometer pipa tegak (standpipe piezometer), yang terdiri atas :

1) Porous-tube pisometer, yakni ujung pipa (mata pizometer) berupa pipa berlubanglubang/perforasi yang porous).

2) Slotted pipe pisometer (mata pisometer dari pipa yang digergaji dengan spasi tertentu).

2. Pipa atau sumur pengamatan

(observation well).

Sedangkan sistem tertutup,

diantaranya adalah :

1) Pizometer pipa ganda hidraulik (hydraulic twin-tube pizometer).

2) Pizometer pnumatik (dengan tekanan gas, pneumatik pizometer).

3) Pizometer elektrik (electric pizometer).

Perhitungan tekanan pori air dalam tubuh bendungan dapat diketahui/dideteksi melalui alat ukur Inclinometer yang sudah terpasang di tubuh bendungan baik itu ketika masa kontruksi dan setelah selesai masa kontruksi (maintenance), dengan pemasangan kabel Piezometer membentang dari tumpuan kiri dan kanan di sambungkan ke Box Instrumen.

Berikut di Tabel 5. Adalah hasil Output Alat Ukur Piezometer. Tabel 6. Data Minimum dan Maximum Alat Ukur Piezometer, dan Grafik 2. Gambaran Rembesan yang Terdapat di Tubuh Bendungan.

Pada saat pemesanan, instrumen dapat ditentukan, dikalibrasi dengankoefisien koreksi suhu individu. Jika diberikan koefisien ini, maka koefisien dapat digunakan menggunakan rumus dan contoh berikut:

Dimana;

$$
\mathrm{ET}=\mathrm{E}+\mathrm{TK}(\mathrm{T} 1-\mathrm{T} 0)
$$

ET : Rekayasa suhu yang dikoreksi.

TK : Koefisien suhu.

T1 : Suhu instrumen saat ini dan

T0 : Suhu dasar atau nol pembacaan (keduanya dalam derajat $\mathrm{C}$ dan direkam dari instrumen termistor internal).

Hubungan matematis antara frekuensi getaran kabel yang dikencangkan dan gaya yang menerapkan tegangan merupakan perkiraan hubungan garis lurus antara kuadrat dari frekuensi yang diukur dan gaya yang diterapkan. Unit pengukuran rekayasa mungkin diturunkan dari frekuensi unit berbasis yang diukur dengan pembacaan Kawat Bergetar dalam tiga cara tradisional. Dari unit periode (t x 107) dan dari 'linier' (f2 / 1000) unit menggunakan dua metode, persamaan linier sederhana atau persamaan polinomial. 
Rumus berikut digunakan untuk pembacaan dalam unit periode.

Dimana;

$$
\mathrm{E}=\mathrm{K}(107 / \mathrm{P} 02-107 / \mathrm{P} 12)
$$

E : Tekanan dalam unit teknik yang dihasilkan.

$\mathrm{K}$ : Ffaktor pengukur periode' untuk unit kalibrasi (diambil dari lemba kalibrasi) P0 : Dasar 'periode' instalasi atau pembacaan nol.

P1 : Pembacaan 'periode' saat ini.

Metode perhitungan ini digunakan oleh Soil Instruments Vibrating Wire Penebang (model RO-1-VW1 atau 2 dan dengan nomor seri mulai VL atau TVL) prosesor internal, untuk menghitung dan menampilkan langsung dilayar LCD penebang, unit berbasis 'teknik' yang diperlukan. Para penebangmembutuhkan basis 'periode' atau nol unit bacaan untuk masuk ke saluran mereka tabel untuk menghitung dan menampilkan unit 'teknik' yang dibutuhkan dengan benar. Jika unit berbasis 'teknik' diperlukan selain unit kalibrasi, maka faktor $\mathrm{K}$ yang benar harus dihitung menggunakan standar hubungan antara unit 'teknik'. Misalnya, jika satuan 'Rekayasa' yang dibutuhkan dalam inci dan unit kalibrasi milimeter, kita dapat mengetahui bahwa $1 \mathrm{~mm}$ sama dengan 0,03937 ", jadi kami akan melakukannya turunkan faktor $\mathrm{K}$ untuk inci dengan mengalikan faktor ' $\mathrm{K}$ ' untuk milimeter sebesar 0,03937 .

Satuan Linear dapat diterapkan pada persamaan polinomial berikut, untuk penghitungan unit teknik ke urutan akurasi yang lebih tinggi.

\section{Dimana;}

$$
\mathrm{E}=(\mathrm{AR} 12+\mathrm{BR} 1+\mathrm{C})
$$

$$
\begin{array}{cl}
\text { E } & \text { : Unit teknik yang dihasilkan } \\
\text { kalibrasi) } & \begin{array}{l}
\text { 'A', 'B' dan „C' } \\
\text { R1 }
\end{array} \\
\text { C Faktor pengukur polinomial A, B dan C (diambil dari lembar } & \\
\text { Nilai ini harus dihitung ulang pada waktu pemasangan sebagai berikut; } & \text { Pembacaan linier saat ini. } \\
\text { transduser pada saat kalibrasi. }
\end{array}
$$

$$
\mathrm{C}=-(\text { AR02 + BR0 })
$$

Dimana;

$$
\begin{aligned}
& \text { A dan B : Faktor pengukur polinomial A dan B (diambil dari lembar kalibrasi) } \\
& \text { R0 = Adalah instalasi 'linier' dasar atau pembacaan nol. }
\end{aligned}
$$

Harap dicatat bahwa tanda nilai ' $\mathrm{C}$ ' yang dihitung ulang haruslah sama dengan nilai asli ' $\mathrm{C}$ ', jadi jika aslinya negatif maka nilai yang dihitung ulang juga harus negatif.

Konversi ke unit 'teknik' selain unit kalibrasi, paling baik dilakukan setelah konversi, dengan menggunakan faktor yang dihitung menggunakan prinsip yang sama seperti yang dinyatakan dalam paragraf terakhir dari bagian 'unit periode'. 


\section{Perhitungan Data Alat Ukur Piezometer.}

Elevasi

$$
\begin{aligned}
\text { : Elevasi dasar }+\mathrm{mH}_{2} \mathrm{O} \\
\qquad: 71.592+20.72=92.309 \\
\mathrm{mH}_{2} \mathrm{O} \quad: 0.1022 \times 202.7=20.72
\end{aligned}
$$

Elevasi dasar : 71.592

(data elevasi diambil pas pemasangan pertama/dasar pondasi) $\mathrm{C} \quad=$ Kohesi

$$
\text { E : Modulus Young }
$$

\begin{tabular}{|c|c|c|c|c|}
\hline \multirow{14}{*}{ Tanggal } & \multirow{12}{*}{ EP.1 } & Serial Number & \multicolumn{2}{|l|}{056415} \\
\hline & & Lokasi Pemasangan & \multicolumn{2}{|c|}{ B4 Main DAM (Timbunan / Hulu) } \\
\hline & & Sta & \multicolumn{2}{|l|}{$1+275$} \\
\hline & & Elevasi Piezometer & \multicolumn{2}{|l|}{71.592} \\
\hline & & $\begin{array}{l}\text { Tanggal } \\
\text { Pemasangan } \\
\end{array}$ & \multicolumn{2}{|c|}{ Monday, May 14, 2018} \\
\hline & & $\mathbf{E}$ & \multirow{2}{*}{\multicolumn{2}{|c|}{$\begin{array}{l}\mathrm{AR}_{1}{ }^{2}+\mathrm{BR}_{1}+\mathrm{C} \\
\mathbf{0 . 0 0 0 0 0 0 3 1 5 1 4 9 5 0 0}\end{array}$}} \\
\hline & & $\mathbf{A}$ & & \\
\hline & & B & \multicolumn{2}{|c|}{-0.2069191000} \\
\hline & & $\mathbf{C}$ & \multicolumn{2}{|c|}{$-\left(\mathbf{A R}_{\mathbf{0}}^{2}+\mathbf{B} \mathbf{R}_{0}\right)$} \\
\hline & & $\mathbf{R}_{0}$ & \multicolumn{2}{|c|}{6629.8} \\
\hline & & $\mathbf{C}$ & \multicolumn{2}{|c|}{1357.98008989} \\
\hline & & $1 \mathrm{kPa}$ & 0.1022 & $\mathbf{m ~ H}_{2} \mathrm{O}$ \\
\hline & \multirow{2}{*}{$\mathrm{R}_{\mathbf{1}}\left(\mathrm{Hz}^{2} / \mathbf{1 0 0 0}\right)$} & \multicolumn{2}{|c|}{ Data Tekanan Air } & \multirow{2}{*}{ Elevasi } \\
\hline & & $\mathbf{E}(\mathbf{k P a})$ & $\mathrm{m} \mathrm{H}_{2} \mathrm{O}$ & \\
\hline $7 / 1 / 2019$ & 5631.5 & 202.7 & 20.72 & 92.309 \\
\hline $7 / 2 / 2019$ & 5632.0 & 202.6 & 20.71 & 92.299 \\
\hline $7 / 3 / 2019$ & 5632.5 & 202.5 & 20.70 & 92.288 \\
\hline $7 / 4 / 2019$ & 5632.9 & 202.4 & 20.69 & 92.280 \\
\hline $7 / 5 / 2019$ & 5633.5 & 202.3 & 20.68 & 92.267 \\
\hline $7 / 6 / 2019$ & 5634.0 & 202.2 & 20.66 & 92.257 \\
\hline 7/7/2019 & 5634.6 & 202.1 & 20.65 & 92.245 \\
\hline 7/8/2019 & 5635.1 & 202.0 & 20.64 & 92.234 \\
\hline 7/9/2019 & 5635.5 & 201.9 & 20.63 & 92.226 \\
\hline $7 / 10 / 2019$ & 5636.0 & 201.8 & 20.62 & 92.215 \\
\hline $7 / 11 / 2019$ & 5636.5 & 201.7 & 20.61 & 92.205 \\
\hline $7 / 12 / 2019$ & 5636.8 & 201.6 & 20.61 & 92.199 \\
\hline $7 / 13 / 2019$ & 5637.5 & 201.5 & 20.59 & 92.184 \\
\hline $7 / 14 / 2019$ & 5637.8 & 201.4 & 20.59 & 92.178 \\
\hline $7 / 15 / 2019$ & 5638.4 & 201.3 & 20.57 & 92.166 \\
\hline $7 / 16 / 2019$ & 5638.9 & 201.2 & 20.56 & 92.155 \\
\hline 7/17/2019 & 5639.6 & 201.1 & 20.55 & 92.141 \\
\hline 7/18/2019 & 5640.2 & 200.9 & 20.54 & 92.128 \\
\hline
\end{tabular}

Tabel 3. Data Monitoring Alat Ukur Piezometer 
Tabel 4. Rekavitulasi Data Maximum dan Minimum Data Alat Ukur Piezometer

\begin{tabular}{|c|c|c|c|c|c|c|c|c|c|c|c|c|}
\hline \multirow{3}{*}{$\mathrm{NO}$} & \multirow{3}{*}{ ASI } & \multirow{3}{*}{ ELEVASI } & \multirow{3}{*}{ STA } & \multirow{3}{*}{$\begin{array}{l}\text { SERIAL } \\
\text { NUMBER }\end{array}$} & \multirow{3}{*}{$\mathrm{R}_{0}$} & \multirow{2}{*}{\multicolumn{3}{|c|}{$\begin{array}{c}\text { DATA TEKANAN AIR } \\
\text { MINIMUM } \\
\end{array}$}} & \multirow{2}{*}{\multicolumn{3}{|c|}{$\begin{array}{l}\text { DATA TEKANAN AIR } \\
\text { MAKSIMUM }\end{array}$}} & \multirow{3}{*}{$\begin{array}{l}\text {-KETERA } \\
\text { NGAN }\end{array}$} \\
\hline & & & & & & & & & & & & \\
\hline & & & & & & $\begin{array}{c}\mathrm{E} \\
(\mathrm{kPa})\end{array}$ & $\begin{array}{c}\mathrm{m} \\
\mathrm{H}_{2} \mathrm{O}\end{array}$ & Elevasi & $\begin{array}{c}\mathrm{E} \\
(\mathrm{kPa})\end{array}$ & $\begin{array}{c}\mathrm{m} \\
\mathrm{H}_{2} \mathrm{O}\end{array}$ & Elevasi & \\
\hline EP.1 & $\begin{array}{l}\text { Main } \\
\text { DAM } \\
\text { (Timbunan } \\
\text { / Hulu) }\end{array}$ & 71.592 & $1+275$ & 056415 & 6629.8 & 199.5 & 20.39 & 91.983 & 202.7 & 20.72 & 92.309 & \\
\hline EP.2 & $\begin{array}{l}\text { Main DAM } \\
\text { (Timbunan } \\
/ \\
\text { ASDAM) }\end{array}$ & 71.592 & $1+275$ & 056416 & 6842.2 & 218.5 & 22.34 & 93.927 & 223.3 & 22.82 & 94.408 & \\
\hline EP.3 & $\begin{array}{l}\text { Main } \\
\text { DAM } \\
\text { (Timbunan } \\
\text { / Hilir) }\end{array}$ & 71.592 & $1+275$ & 056417 & 6583.3 & 185.7 & 18.98 & 90.567 & 189.9 & 19.41 & 91.005 & \\
\hline EP.4 & $\begin{array}{l}\text { Main DAM } \\
\text { (Timbunan } \\
\text { / Hulu) }\end{array}$ & 82.592 & $1+275$ & 056418 & 6867.5 & 224.3 & 22.92 & 105.511 & 1682.3 & 171.93 & 254.523 & \\
\hline EP.5 & $\begin{array}{c}\text { Main } \\
\text { DAM } \\
\text { (Timbunan } \\
/ \\
\text { ASDAM) }\end{array}$ & 82.592 & $1+275$ & 056419 & 6943.2 & 151.7 & 15.50 & 98.093 & 1689.1 & 172.62 & 255.217 & \\
\hline EP.6 & $\begin{array}{l}\text { Main DAM } \\
\text { (Timbunan } \\
\text { / Hilir) }\end{array}$ & 82.592 & $1+275$ & 056420 & 6464.8 & 101.8 & 10.41 & 93.000 & 1254.8 & 128.24 & 210.827 & \\
\hline EP.7 & $\begin{array}{l}\text { Main } \\
\text { DAM } \\
\text { (Timbunan } \\
\text { / Hulu) }\end{array}$ & 92.592 & $1+275$ & 056421 & 6780.8 & 101.3 & 10.35 & 100.224 & 116.3 & 11.89 & 101.398 & \\
\hline EP.8 & $\begin{array}{l}\text { Main DAM } \\
\text { (Timbunan } \\
/ \\
\text { ASDAM) }\end{array}$ & 92.592 & $1+275$ & 056422 & 6728.2 & 20.8 & 2.13 & 94.722 & 27.8 & 2.84 & 95.431 & \\
\hline EP.9 & $\begin{array}{l}\text { Main } \\
\text { DAM } \\
\text { (Timbunan } \\
\text { / Hilir) }\end{array}$ & 92.592 & $1+275$ & 056423 & 6536.0 & 0.0 & 0.00 & 92.588 & 0.2 & 0.02 & 92.609 & \\
\hline EP.10 & $\begin{array}{l}\text { Main DAM } \\
\text { (Timbunan } \\
\text { / Hulu) }\end{array}$ & 102.592 & $1+275$ & 056424 & 6952.4 & 20.3 & 2.08 & 104.670 & 37.3 & 3.81 & 106.403 & \\
\hline EP.11 & $\begin{array}{c}\text { Main } \\
\text { DAM } \\
\text { (Timbunan } \\
/ \\
\text { ASDAM) }\end{array}$ & 102.592 & $1+275$ & 059117 & 6428.4 & -2.9 & -0.29 & 102.300 & 1.3 & 0.13 & 102.720 & \\
\hline EP.12 & $\begin{array}{l}\text { Main DAM } \\
\text { (Timbunan } \\
\text { / Hilir) }\end{array}$ & 102.592 & $1+275$ & 059118 & 6811.2 & -3.5 & -0.35 & 102.238 & -3.0 & -0.31 & 102.284 & \\
\hline
\end{tabular}




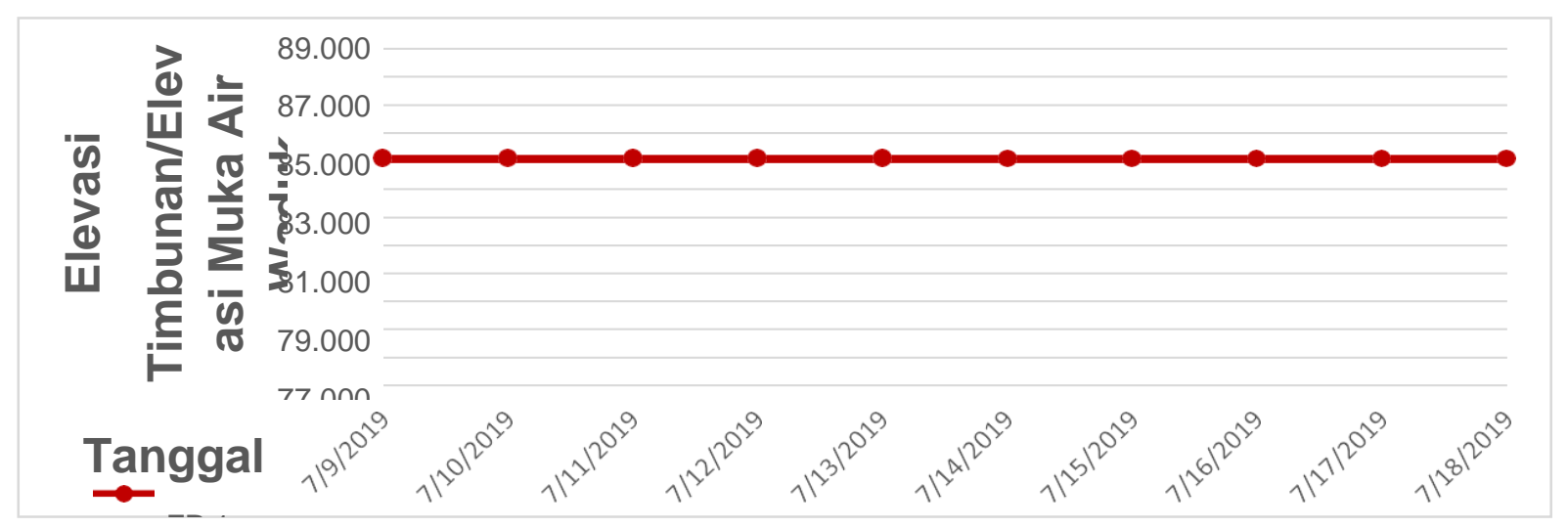

Grafik 2. Elevasi Rembesan Pori Air Muka Air Waduk (Bendungan)

\section{Keterangan :}

$=$ Rembesan yang terdapat di dalam tubuh Bendungan setelah masa impounding.

\section{Hasil Uji Kepadatan Tanah Data Sencone dan CBR (California Bearing Ratio)}

Untuk memenuhi persyaratan spesifikasi teknis, pada umumnya harus dilakukan pengujian kepadatan laboratorium untuk material tanah atau lapis dasar pondasi yang digunakan dan kepadatan lapangan harus memenuhi persentase tertentu (misal 95\% atau 98\% atau 100\%) dari kepadatan laboratorium yang disyaratkan dalam spesifikasi yang berlaku pada proyek yang bersangkutan.

Dimana :

$$
\begin{aligned}
& 100 \% \mathrm{Vd}=1970 \mathrm{gr} / \mathrm{cm}^{3} \quad \text { OMC }=12 \% \\
& 95 \% \mathrm{Vd}=\ldots . . \mathrm{gr} / \mathrm{cm}^{3} \quad \mathrm{MC}=\ldots . . \\
& \mathrm{Ys}=1460 \mathrm{gr} / \mathrm{cm}^{3} \quad \text { Berat pasir dalam corong }=1.307 \mathrm{gr}(\mathrm{Wt})
\end{aligned}
$$

Tabel 5. Data Hasil Sencone Tanah Timbunan

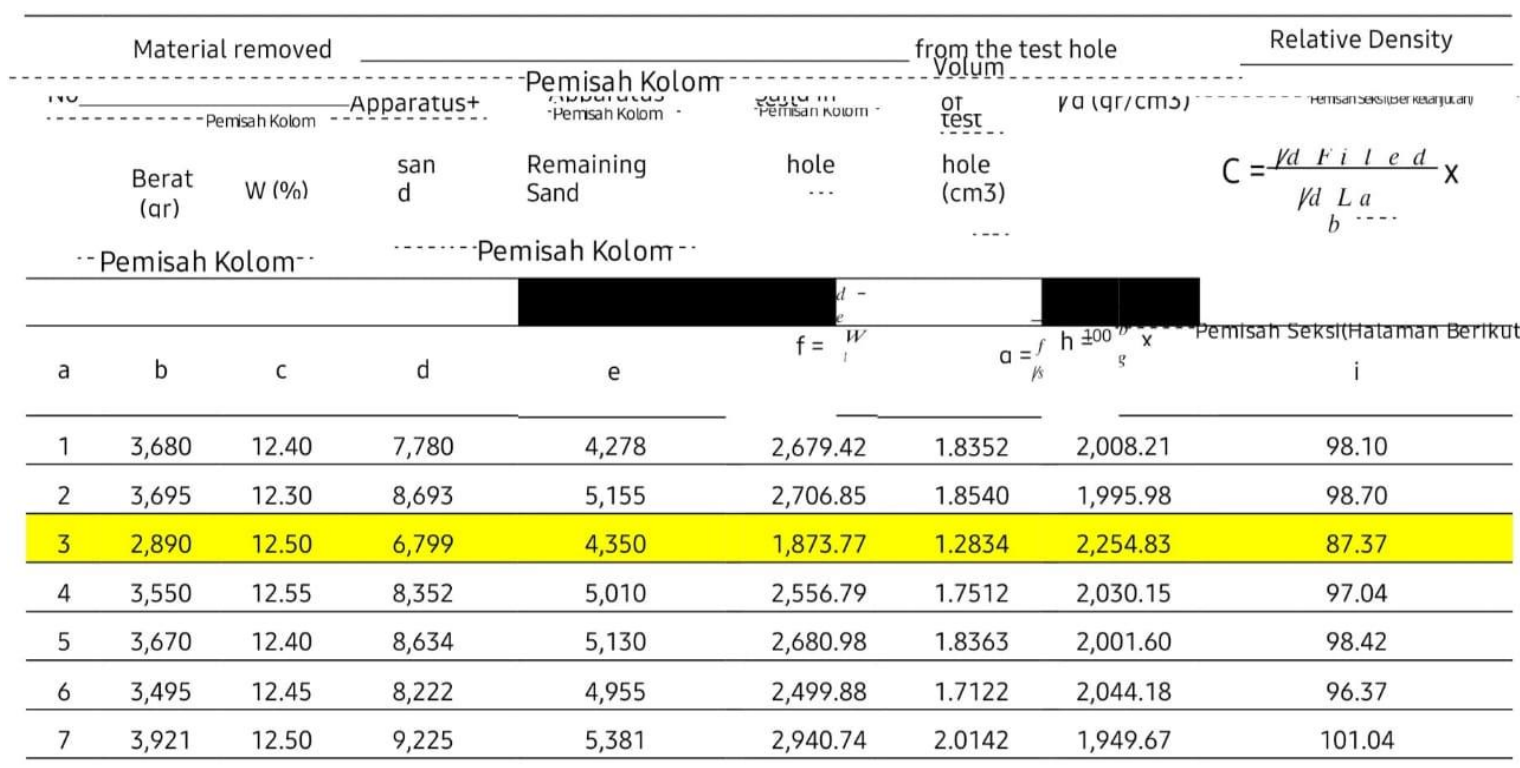


Data Hasi CBR (California Bearing Ratio) adalah perbandingan antara beban penetrasi suatu lapisan tanah atau perkerasan terhadap bahan standar dengan kedalaman dan kecepatan penetrasi yang sama.

Tabel 6. Hasi CBR (California Bearing Ratio)

\begin{tabular}{rcccc}
\hline Waktu (Menit) & Penurunan (mm) & Pembacaan Alroji & Beban (Kg) & $\begin{array}{c}\text { Tegangan } \\
\left(\mathrm{Kg} / \mathrm{mm}^{2}\right)\end{array}$ \\
\hline 0.25 & 0.32 & 3.5 & 87 & 0.04 \\
0.50 & 0.64 & 6.1 & 151 & 0.07 \\
1.00 & 1.27 & 11 & 271 & 0.13 \\
1.30 & 1.91 & 17 & 424 & 0.21 \\
2.00 & 2.54 & 21 & 523 & 0.26 \\
3.00 & 3.81 & 3 & 743 & 0.37 \\
4.00 & 5.08 & 37 & 920 & 0.45 \\
6.00 & 7.62 & 51 & 1267 & 0.63 \\
8.00 & 10.16 & 62 & 1538 & 0.76 \\
10.00 & 12.7 & 69 & 1716 & 0.85 \\
\hline
\end{tabular}

\begin{tabular}{lcc}
\hline CBR & \multicolumn{3}{c}{ Penurunan } \\
\hline Nilai CBR & $\frac{0.254 \mathrm{~cm}}{0.71} \times 100 \%=40 \%$ & $\frac{0.48}{1.0} \times 100 \%=46 \%$ \\
\hline
\end{tabular}

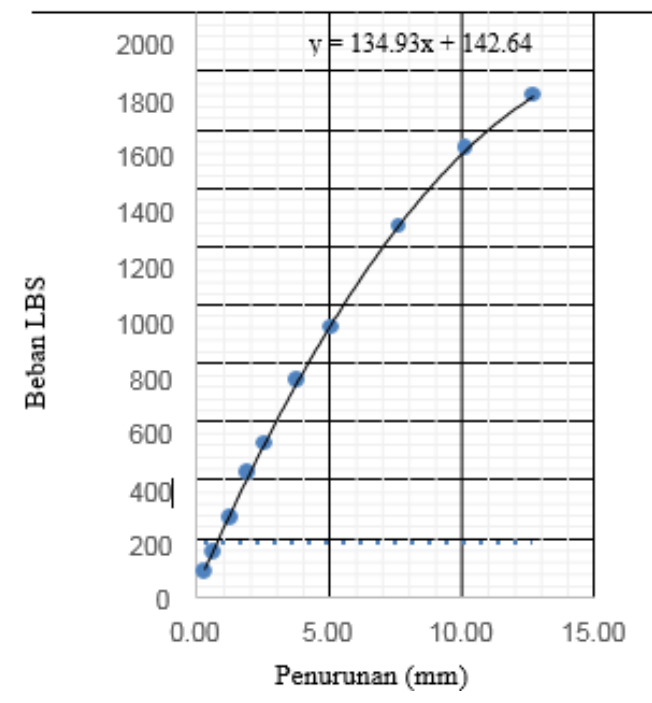

Grafik 3. Hasil CBR

\section{KESIMPULAN}

1. Penurunan Struktur yang dipengaruhi tekanan air tampungan bendungan dan alam (curah hujan dan gempa) yang menghasilkan gaya geser (gerak vertical,horizontal) dapat di ukur/diketahui melalui alat ukur instrumen geoteknik inclinometer, pizometer dan data pemadatan tanah sepetri sencone dan CBR sebagai perbandingan.

2. Terjadinya penurunan struktur atas Bendungan Sindang Heula bukan di sebabkan karrna adanya rembesan atau pun gaya yang bekerja pada tubuh bendungan, hal ini diketahui setelah melalui tahapan observasi di lapangan dengan cara perhitungan hasil data ukur alat inclinometer, piezometer, sencon dan CBR. 
3. Permasalahan penurunan struktur atas Bendungan Sindang Heula disebabkan karna adanya penyusutan matrial timbunan exstra embankmet hal ini diketahui dari hasil perhitungan data Piezometer.

\section{SARAN}

1. Pemasanagan Intrumen Geoteknik pada suatu bendungan harus mengacu pada sifat-sifat perlapisan yang di pengaruhi oleh factor-faktor sejarah geologi, waktu dan beban-beban lain yang bekerja. Pada dasar nya intrumen geoteknik yang dipasang pada bendungan harus memenuhi beberapa persyaratan.

2 Sebaiknya pemasangan instrumen inclinometer dan piezometer dilakukan pada saat atau selama kontruksi, kita akan dapat memprediksi kondisi bangunan dan kinerjanya serta juka di temui penyimpangan/bias segera dilakukan perbaikan.

3. Pada bendungan-bendungan lama, juga biasa di prediksi kinerja dan keamanan serta kodisinya apakah dalam kondisi aman atau tidaknya. Sehingga dapat memberi masukan untuk pemeliharaan kedepanya.

\section{DAFTAR PUSTAKA}

Carlina Soetjiono \& Najoan, T.F., 1993. Instrumentasi Geoteknik dalam Evaluasi Keamanan Bendungan Tipe Urugan. Jurnal Litbang Pengairan No.26; ISSN 0215-1111.

Carlina Soetjiono, 2009. Penerapan metode indeks risiko untuk evaluasi tingkat keamanan bendungan urugan. Prosiding Kolokium Hasil Litbang SDA Bekasi, ISSN: 1829-9644.

Djuri, M., Samodra, H., Amin, T. C. \& Gafoer, S. 1996. Peta Geologi Lembar Purwokerto dan Tegal, Jawa. Skala 1:100.000. Puslitbang Geologi. Bandung.

Gultom, Anju Frisco, dan Sebayang, Agustinus. 2009. Analisis Stabilitas Bendungan Way Biha Lampung. Tugas Akhir.

Bandung: Jurusan Teknik Sipil dan Lingkungan. Institut Teknologi Bandung.

Juenal Karya Teknik Sipil, Volume 4, Nomor 4, Tahun 2015, Halaman 561 - 567 Online di: http://ejournals1.undip.ac.id/index.php/jkts.

Kementrian, PU. 2004. Analisis Stabilitas Bendungan Tipe Urugan Akibat Gempa, Pedoman Konstruksi dan Bangunan,

Pd T-14-2004-A.

Modul Instrumentasi Bendungan Urugan Pelatihan Perencanaan Bendungan Tingkat Dasar.

Najoan, Th.F. dan Carlina Soetjiono (2002), "Pedoman Metode Stabilitas Lereng Statik Bendungan Tipe Urugan",

RSNI M-03-2002, Balitbang, Dep. Kimraswil 2002.

Najoan, Th.F. dan Carlina Soetjiono (2004), "Pedoman Instrumentasi Tubuh Bendungan Tipe Uingan dan Tanggul",

Pd T-08-2004-A, Balitbang, Dep. Kimraswil 2004.

Puslitbang Sumber Daya Air (2004), "Pengkajian dan Evaluasi Keamanan Bendungan Pasca Rehabilitas di Jawa Tengah”, Desember 2004, Laporan Penelitian No. 03/P2TP \& SP/2004 Puslitbang SDA.

Peneliti Balai Bangunan Hidraulik dan Geoteknik Keairan Pusat Litbang Sumber Daya Air.

Puslitbang Sumber Daya Air, 2004. Pengkajian dan Evaluasi Keamanan Bendungan Pasca Rehabilitasi Di Jawa Tengah. Laporan Akhir Penelitian No. 03/P2TP \& SP/2004.

Peraturan Pemerintah Republik Indonesia Nomor 37 Tahun 2010 tentang Bendungan (Lembaran Negara RI Ta hun 2010 No. 45, Tambahan Lembaran Negara RI No. 5117).Presiden Republik Indonesia, ditetapkan di Jak arta, tanggal 18 Februai2010.

SNI 3404:2008. "Tata Cara Pemasangan Inclinometerdan Pemantauan Pergerakan Horizontal Tanah".

Undang-Undang Republik Indonesia Nomor 7 Tahun 2004 tentang Sumber Daya Air (Lembaran Negara RI Tahun 2004 No. 32, Tambahan Lembaran Negara RI No. 4377). Presiden Republik Indonesia, disahkan dan diundangkan di Jakarta, tanggal18 Maret 2004. 